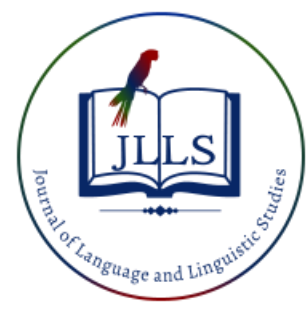

Available online at www.jlls.org

JOURNAL OF LANGUAGE AND LINGUISTIC STUDIES

ISSN: 1305-578X

Journal of Language and Linguistic Studies, 17(4), 1998-2021; 2021

\title{
Foreign language teachers' technological and pedagogical content knowledge: A study with AFL teachers in Indonesia
}

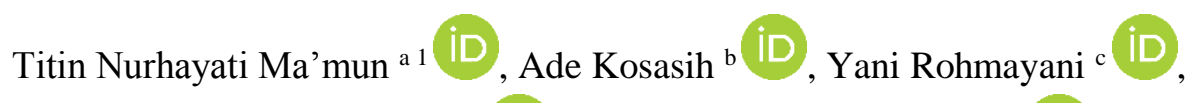 \\ Eka Kurnia Fimansyah d iD, Mohammad H. Al-khresheh e (iD) \\ ${ }^{a, b, c, d}$ Universitas Padjadjaran, Indonesia \\ ${ }^{e}$ Northern Border University, Saudi Arabia
}

\section{APA Citation:}

Ma'mun, T. N., Kosasih, A., Rohmayani, Y., Fimansyah, E.K., \& Al- khresheh, M. H. (2021). Foreign language teachers' technological and pedagogical content knowledge: A study with AFL teachers in Indonesia. Journal of Language and Linguistic Studies, 17(4), 1998-2021. Doi: $10.52462 / \mathrm{jlls} .145$

Submission Date: $15 / 05 / 2021$

Acceptance Date: $18 / 08 / 2021$

\begin{abstract}
Teaching-learning of the Arabic language has emerged as vital in both Muslim and non-Muslim countries. However, a lack of studies exists on measuring the technological pedagogical content knowledge (TPACK) of Arabic language teachers. Thus, this study explores Indonesian Arabic teachers' TPACK and provides a conceptualization that the elements of TPACK are not separate; rather, each element facilitates the sustenance of other elements. To achieve this objective, a quantitative research approach is undertaken using a validated and reliable questionnaire. Data is collected from 320 teachers (snowball sampling) using Google forms. The data analysis reflects the inter-relation of the elements of TPACK, with a satisfactory TPACK of the Indonesian Arabic teachers. Additional findings suggest that teachers use technology minimally in designing tasks or even assessments despite their strong technological background. Further studies are recommended to explore teachers' roles, teacher development programs, and religious motivation in achieving higher TPACK of Arabic language teaching.
\end{abstract}

Keywords: TPACK; Arabic language; language education; technology in tasks; technology in assessment.

\section{Introduction}

Studies conducted in non-Muslim pluralist societies often raise controversies on the importance of mandatory Arabic language learning (Sai, 2017). However, learning the Arabic language in Muslim communities inevitably impacts from a language acquisition viewpoint and a religious (Islamic) point of view (Wekke, 2017). Contrasting studies even emphasize the need to promote a unified Islamic curriculum for teaching the Arabic language throughout Muslim Nations (Karimizadeh \& Abolghasemi, 2016). While studies also show young adults' recognition of Arabic as the language of Islam (Sibgatullina, 2020), some other studies advocate the study of Quran under linguistic studies for simultaneously promoting the learning of Qur'an, language, religion, and science (Ali et al., 2020). Nevertheless, the underlying fact remains that Arabic is considered a substantial foreign language or

\footnotetext{
${ }^{1}$ Corresponding author:

E-mail address: titin.mamun@unpad.ac.id
} 
even second language in many countries. Little researches have been conducted on the factors that play in the Arabic teaching-learning environment (Alwaleedi, 2017).

Regardless of the religious or communal impact, any foreign language learning comes with

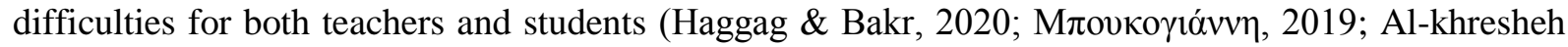
\& Al-Ruwaili, 2020; Al-khresheh, 2020; Alkodimi \& Al-Ahdal, 2021). The Arabic language has more complex morphological and syntactic systems than any other European language, including English (Alwaleedi et al., 2019; Wahba et al., 2017), which makes the teaching and learning of Arabic even more challenging for the teachers and learners. Several studies indicate the students' difficulties while learning Arabic, either as a second language or a foreign language (Al-busaidi et al., 2016; Amer, 2020; Zurqoni et al., 2020). The reasons behind these difficulties range from lack of vocabulary, formation of verbs in the Arabic language, even inadequate environmental support, and lack of opportunity to practice Arabic outside the classroom (Zurqoni et al., 2020).

In addressing students' learning difficulties, the constructivist theory of education advocates teachers' role to facilitate the learning to reach the individual's zone of proximal development (Vygotsky, 1980). Specifically, in bilingual education, where two parallel languages are simultaneously taught to students, educators worldwide call for revolutionizing the traditional pedagogical methods (Schwartz \& Asli, 2014). What more could be suggested is embracing new techniques for combining blended learning, online and face-to-face learning in this time of the global pandemic that has affected language teaching as much as any learning (Ahmadi \& Ilmiani, 2020). In doing so, researchers have emphasized that teachers' content knowledge (CK) or pedagogical knowledge (PK) separately might not be enough, and there is an urgent need to develop teachers' pedagogical content knowledge (PCK) to teach the Arabic language successfully (Saidah et al., 2018).

However, the massive advancement in technology has taken over education, especially considering that the pandemic situation has established the need to incorporate technological aspects in teaching to ensure smooth conduct of online classes, recorded lectures, assignment submission, etc. (Al Lily et al., 2020; Al-khresheh, 2021; Mahundu, 2020). In terms of language teaching, researchers indicate the importance of technological knowledge (TK) and technological content knowledge (TCK) as integrated aspects of teaching and implementing through pedagogical strategies; hence the need for acknowledging technological pedagogical knowledge (TPK) emerges as crucial (Alharbi, 2019).

The underlying theory behind combining teachers' content knowledge (CK), technological knowledge (TK), pedagogical knowledge (PK), pedagogical content knowledge (PCK), technological content knowledge (TCK), and technological pedagogical knowledge (TPK), hence the total package was introduced by Koehler and Mishra (2005) Technological Pedagogical Content Knowledge (TPACK) lies on,

'Learning by design appears to be an effective instructional technique to develop deeper understandings of the complex web of relationships between content, pedagogy and technology and the contexts in which they function.' (pp.131)

Although several studies have been undertaken to measure teachers' TPACK in different disciplines after its first conceptualization (Willermark, 2018), very few studies were undertaken in exploring Arabic teachers' TPACK (Alharbi, 2019). Therefore, this study fills an existent gap in knowledge by exploring Indonesian Arabic language teachers' TPACK through a validated and reliable instrument adapted from the literature (Bostancioğlu \& Handley, 2018).

In doing so, a primary significance of this study lies in reconceptualizing a more comprehensive vision of TPACK: Maslow's Hierarchy of Need point of view and recognizing the elements of TPACK are not separate; instead, the elements sustain each other at different levels of advancement of teaching. An additional literature search indicates the existing gap in the Indonesian context in 
exploring TPACK of the Arabic language teachers. One central research question was formulated, which was subdivided into three sub-questions:

How far is the constitution of TPACK for the Indonesian Arabic teachers?

Guided by this main research question, the study also seeks to determine the extent to which Indonesian Arabic teachers' CK, TK, TCK, TPK, and PCK contribute to their overall TPACK. Thus, the following sub-questions are formulated:

1.a) To what extent do the Indonesian Arabic teachers' CK and TK contribute to their TPACK?

1.b) To what extent do the Indonesian Arabic teachers' TCK, TPK, and PCK contribute to their TPACK?

1.c) What is the Indonesian Arabic teachers' overall TPACK?

\section{Literature Review}

\subsection{The Re-emergence of interest in the Arabic Language in Islamic and Non-Islamic Countries}

Islam, being not just a religion but more of a life-long practice of lifestyle, requires its practitioners to use the Arabic language daily - from calling for prayers (adhan) and five prayers a day (Salah), religious activities including reciting Quran and Hadith, and understanding the meaning of life, all regardless of Arab or non-Arab countries (Ahmad, 2001). Several Muslim countries require Arabic language fluency for Islamic studies as an option in higher education, focusing on the knowledge of basic sources of Islamic studies- Quran, Hadith, through all of which are primarily in Arabic language (Aziz et al., 2016). Along with Islamic studies, the UK government has recognized the need to incorporate the Arabic language for Middle Eastern Studies under modern foreign languages, discounting the notion of radicalization of British Muslims (Bernasek \& Canning, 2009). As the world moves towards more technological advancement, the Arabic language keeps up with its pace by incorporating modern technology as a teaching-learning tool (Sulaiman, 2015). Not only that, but the vision of the Arabic language also copes with the $21^{\text {st }}$-century competencies required for globalization (Sains, 2019; Habibi et al., 2019; Al-khresheh et al., 2020). Thus, it becomes undeniable to overlook the rise of the language, which demands more research in the Arabic language.

\subsection{TPACK-The Total Package}

In conceptualizing the total package-TPACK, the following figure (Figure 1) visualizes interaction among the elements. It was envisaged primarily by Koehler and Mishra (2005) to understand the interrelationship between teachers' cognitive and thinking aspects with teachers' action and observable effects. Since the model was introduced, it has gained a lot of attention from researchers worldwide and is considered one of the revolutionary visions in education. Many researchers, including the authors themselves, reviewed and explained the model several times (Brantley-Dias \& Ertmer, 2013; Koehler et al., 2013; Tweddell, 2015). 


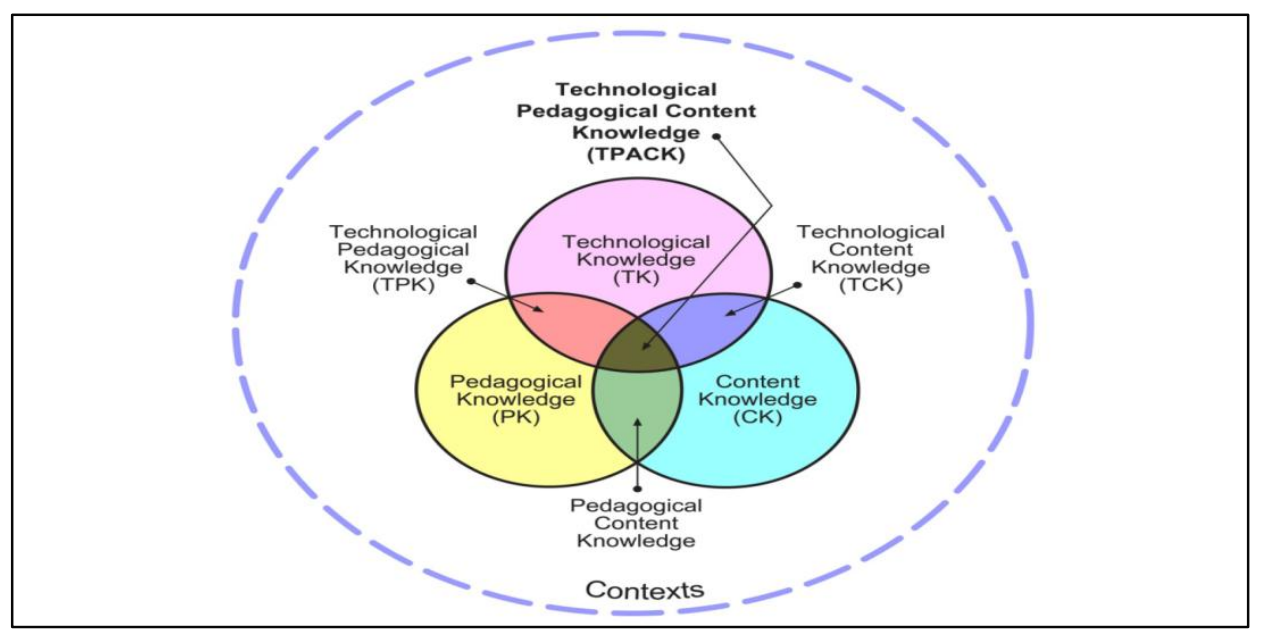

Figure 1. Conceptualization of TPACK (Koehler \& Mishra, 2005)

Teaching is inevitably a complex activity, especially in combining teachers' content knowledge with pedagogical skills incorporating technological advancement. Previous attempts to explore teaching qualities focused on the pedagogical aspects and technological aspects as separate entities but the drastic advancements in $21^{\text {st- }}$ century teaching call for integrating the pedagogical strategies' technological aspects (Niess, 2011).

\subsection{Educational Learning Theories for TPACK}

Primarily based on Shulman's theory of pedagogical content knowledge (Shulman, 1987;1986), the idea of TPACK feeds on different educational theories of learning. Considering the teaching processes worldwide are going through a paradigm shift to move from a behaviorist approach to a more constructivist and humanist approach (Cooper, 1993), the idea of TPACK becomes an umbrella concept that integrates different mechanisms of constructivist and humanist theory. Constructivism advocates for students' learning facilitated by the teacher, thus not only gaining knowledge by lectures or instructions but also taking ownership of the learning through promoting self-efficacy and selfdetermination (Baviskar et al., 2009; Confrey, 1995; Deci \& Ryan, 2010; Gray, 1997; Schunk, 1991). TPACK, containing pedagogical aspects with technological strategies, enables the students to take autonomy of their learning and provides teachers with opportunities to incorporate pedagogical strategies which allow the students to use technological aspects in active learning. Given that the Humanism theory of learning considers other non-cognitive variables of students, such as motivation, curiosity, the creativity of learners (Huitt, 2009), the concept of TPACK promotes the learners' use of technology in the teaching-learning system, which enables them to foster their creativity, learning curiosity and addressing their motivation. Overall, the concept of TPACK integrates almost all aspects of teaching, which has been emphasized as essential for learning achievement over the years.

\subsection{Major Elements of TPACK from Arabic Language Point of View}

Figure 1 indicates the seven elements of TPACK. These elements are amplified from the Arabic language teaching perspective, sequenced by simple knowledge to complex knowledge.

Content Knowledge, Pedagogical Knowledge, and Technological knowledge in the Arabic Language

In general, Shulman (1986) defined content knowledge as 'concepts, theories, ideas, organizational frameworks, evidence and proof, and established practices and approaches toward developing such knowledge'. However, being specific to the Arabic language, three major components are indicated as 
the most critical content knowledge by Zakaria et al. (2019), viz. grammatical knowledge/syntax, Arabic morphology, and Balaghah (the art of speaking). Nevertheless, literature often advocates that having competence in content knowledge does not always reflect on the pedagogical aspect (Depaepe \& König, 2018). Pedagogical knowledge is defined as a 'specialized body of teachers' knowledge for creating effective teaching and learning environments for all students' (Sonmark et al., 2017, p.11). It is further emphasized that such pedagogical knowledge can be gained by appropriate and adequate training and experience. It should have four dimensions: Structure, motivation and classroom management, adaptivity, and classroom management (Guerreiro, 2017). In terms of the pedagogical knowledge of Arabic language teaching, Alghamdi (2014) introduced six themes: Constructivism, relevance, the dynamic approach according to students' needs, connection, teachers' beliefs, assumptions, and expectations about knowledge, and lastly, technological knowledge, which is considered as more 'flux' than other two streams of knowledge (Koehler et al., 2013), described as a manner 'which enables a person to accomplish a variety of different tasks using information technology and to develop different ways of accomplishing a given task' (Koehler et al., 2013, p. 15). Technological knowledge in the Arabic language, in reality, is going beyond just installing computers; rather it involves developing conducive software and word processing applications that can facilitate language internalization (Ismail et al., 2010).

Pedagogical Content Knowledge, Technological Pedagogical Knowledge, and Technological Content Knowledge in the Arabic language

Pedagogical content knowledge emerged as a procedural way to address the "missing paradigm" and became one of the widest envisioned concepts in the 1980s (Shulman, 2019). It impacted policy on certification and evaluation of teachers and developing and evaluating teacher development programs to increase the quality of education (Deng, 2018). The scope of pedagogical content knowledge was simply explained by Koehler et al. (2013) as,

'PCK covers the core business of teaching, learning, curriculum, assessment, and reporting, such as the conditions that promote learning and the links among curriculum, assessment, and pedagogy'. (pp. 15)

In teaching Arabic, PCK comes as a significant attribute (Azizan et al., 2017). It comprises the teachers' content knowledge and pedagogical knowledge towards achieving the target learning outcomes of the Arabic language. Precisely, in the Arabic language, PCK consists of teachers' competence in transforming Arabic content knowledge for teaching, adapting and improvising the Arabic content materials, addressing students' prior knowledge, and appropriate assessment (Jwaifell et al., 2018).

On the other hand, with raising advancement of technology, technological content knowledge becomes essential regardless of the discipline of the teaching area. It primarily refers to the knowledge on ICT (Information and Communication Technology) tools that potentially can be utilized to represent and research the subject matter, except for pedagogical concerns (Koh \& Chai, 2016). To address $21^{\text {st }}$-century learning skills like communication, collaboration, construction, innovation, and regulation, knowledge of technological content becomes indispensable (Herring et al., 2016; Orak \& Al-khresheh, 2021). Specifically, in Arabic language teaching, TPK contributes in a wider range, considering the teachers' competence in using ICT in their teaching process, in designing teaching approaches, assessment tools, ensuring not only students' engagement but also promoting students' ICT skills in the course of Arabic lessons (Alayyar et al., 2012).

As emphasized before, technological advancement is emerging in all aspects and integration of technology in pedagogy comes as the need of the times, considering it offers round-the-clock connectivity, advanced teaching materials, digital footprints on education through online classes, and 
so on (Ratheeswari, 2018). Technological pedagogical knowledge was simply defined by Valtonen et al. (2019) as,

'Knowledge of how to take advantage of appropriate ICT for supporting certain teaching and learning approaches without considering the subject matter.' (pp.493)

Considering all the literature sources, this study offers the following diagram to conceptualize TPACK for the Arabic language. The diagram is inspired by Maslow's (1989) Hierarchy of Needs; in this case, these needs are classified based on the most efficient Arabic language teaching requirements. Thus, the basic need for knowledge is at the bottom as the most important, in the simplest form of knowledge (CK, PK and TK). The complexity of teaching comes consequently, and TPACK or the total package can be considered as the highest achievement level. The study also finds TCK, PCK, and TPC not as separate entities but simultaneously feed one another.

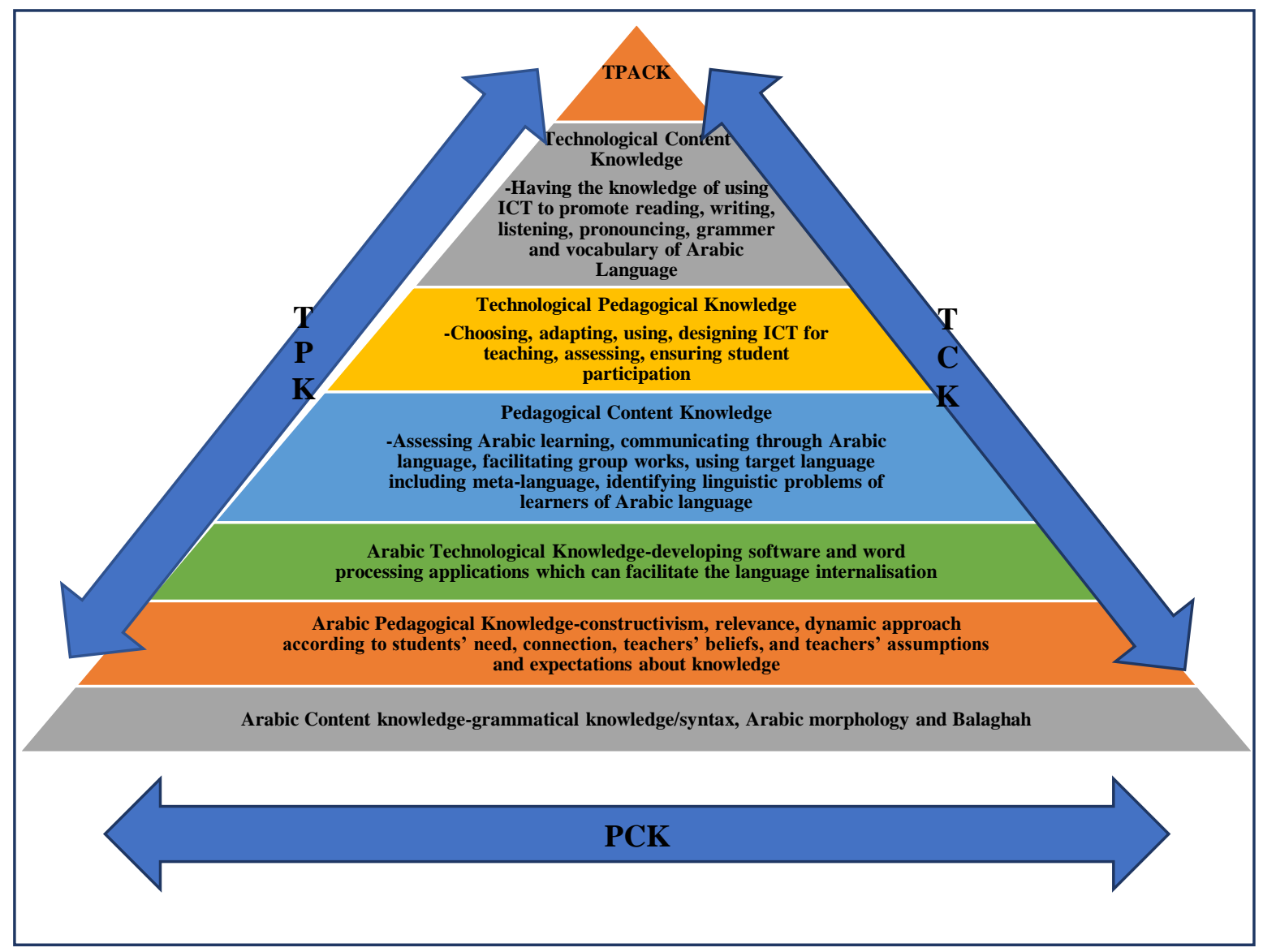

Figure 2. Conceptualizing TPACK, inspired by Maslow's pyramid of need

\subsection{Studies Related to TPACK for the Arabic Language}

Since the conceptualization of TPACK began, there have been several attempts worldwide in developing instruments to measure teacher quality, and thus, offer development programs for teachers, even evaluate the teacher development programs based on the conceptualization of TPACK (BrantleyDias \& Ertmer, 2013; Koehler et al., 2013; Tweddell, 2015). Yet, preliminary studies exist in exploring Arabic teachers' TPACK (Alharbi, 2019), emphasizing the lack of appropriate instruments to measure Arabic language teachers' TPACK (Bostancioğlu \& Handley, 2018). An exploration of literature regarding TPACK of teachers of Arabic as a second or foreign language showed only one study in the Turkish context on teachers' readiness to incorporate flipped classroom strategy (Jwaifell 
et al., 2018). One more study was identified that focused on Saudi Arabian teachers' TPACK for Arabic language teaching. Still, the moot point is that Arabic is not a foreign or second language in Saudi Arabia (Bingimlas, 2018).

In the context of this study, Indonesian teachers' TPACK was measured in different studies for different disciplines but mostly in teaching science-related subjects (Muhaimin et al., 2019; Setiawan $\&$ Phillipson, 2020). Two studies have been found in the literature, which measured the TPACK of teachers for English as a foreign language (Drajati et al., 2018). Yet, there has been no attempt to measure the TPACK of Arabic teachers in the context of Indonesia.

Arabic is considered one of Indonesia's most important disciplines, considering its association with Islam (Ritonga et al., 2020). In addition, Arabic in Indonesia impacts industrialization (Albantani \& Madkur, 2019), commerce, science, and culture (Tohe \& Malang, 2018). Thus, studies have been conducted to improvise the instructional materials to communicate with the Arabic language (Yani \& Sara, 2018), even transforming the dictionaries to understand better and learn the language (Taufiqurrochman, 2020). Yet, the research gap remains in exploring the TPACK of Arabic language teachers. This might be due to the lack of instruments to measure Arabic language teachers' TPACK until Bostancioğlu and Handley (2018) developed a valid and reliable instrument. However, two years after the instrument's development, there is still no research existing in the literature that measures the TPACK of Arabic language teachers in Indonesia. To bridge this gap, this study explores Arabic teachers' TPACK in Indonesia's context.

\section{Methodology}

\subsection{Research Aim and Approach}

The study seeks to explore the elements and the interrelation among the elements of TPACK of Arabic language teachers in Indonesia. In doing so, the study follows a quantitative approach. According to Creswell (2012), the quantitative approach applies when the variables are in large numbers and can be expressed numerically and analyzed statistically.

\subsection{Participants}

To reach the maximum number of eligible participants, the snowball sampling technique is recommended to achieve the target sample (Naderifar et al., 2017), followed in this study for sampling the participants. In the beginning, the instrument was given to 5 university teachers to disseminate to Arabic language teachers. In total, 329 participants responded and showed their willingness to participate in the study. Then using scrutiny based on the last open-ended questions' responses, nine responses were eliminated, considering their irrelevance. So, the final sample size came to 320 .

In general, all the participants were Arabic language teachers; approximately one-third of them had received teacher training in content knowledge, pedagogical knowledge, or technological knowledge.

\subsection{Instrument}

To measure the TPACK of Indonesian teachers for teaching Arabic as a foreign language, this study uses a modified version of the valid and reliable instrument developed by Bostancioğlu and Handley (2018), which was initially developed to measure teachers' TPACK of teaching English as a foreign language. The validity of the revised instrument was established through expert validation, and further, Cronbach Alpha was measured to establish the instrument's reliability. The final instrument consists of 36 items under six constructs using a 5-point Likert scale for responses. The instrument's 
confirmatory factor analysis merged pedagogical knowledge and pedagogical content knowledge as one construct-pedagogical content knowledge.

\subsection{Data Collection and Analysis}

The primary data was collected by approaching the University teachers who disseminated the questionnaire to the target participants. The data was collected online, using Google Forms. Data analysis was done using the software: (a) SPSS to test the instrument's internal consistency (Cronbach Alpha); (b) JASP for descriptive analysis; (c) Microsoft Excel to compile the statistical data analysis, (d) M+ for modeling; and (e) R for plotting.

\subsection{Validity and Reliability of the instrument}

The validity was established in the published instrument through expert validation on items, content validation and construct validation. Starting from a total of 76 items, the number of validated items was 55. In addition, exploratory and confirmatory factor analysis was undertaken to establish construct validation, resulting in 36 items under six constructs. Thus, the instrument which is used in this study confirmed its validity.

According to Peters (2018), Cronbach's Alpha value establishes the instrument's internal consistency (reliability) as excellent when the value is more than 0.93. In this study, the overall Cronbach Alpha value was 0.954 , which proves the instrument is reliable. The item-specific Cronbach Alpha value is given in Appendix 1, Table 1.

\section{Results and Analysis}

In this section, the results are presented with an additional analysis of the findings. The descriptive analysis of the overall results is given in Appendix 2, Table 2. The research instrument marginalized the pedagogical knowledge to pedagogical content knowledge. The following section presents the simplest forms of knowledge (CK and TK); the complex forms of knowledge in the second section (PCK, TPK, and TCK). The third section presents the overall TPACK with an additional representation of inter-relationships among the elements of TPACK.

\subsection{Teachers' Content Knowledge and Technological knowledge contributing to TPACK}

Participant Indonesian Arabic language teachers' content knowledge, as analyzed in Figure 3 shows teachers' general high agreement towards their perception of having content knowledge about the Arabic language. The highest content knowledge on the Arabic language was measured in their competence to monitor their speech (C2). The teachers had the highest percentage of strong agreement when asked about their competence in comprehending Arabic texts correctly (C4). Teachers showed more neutral agreement in evaluating their competence in monitoring their writing accuracy (C1). 


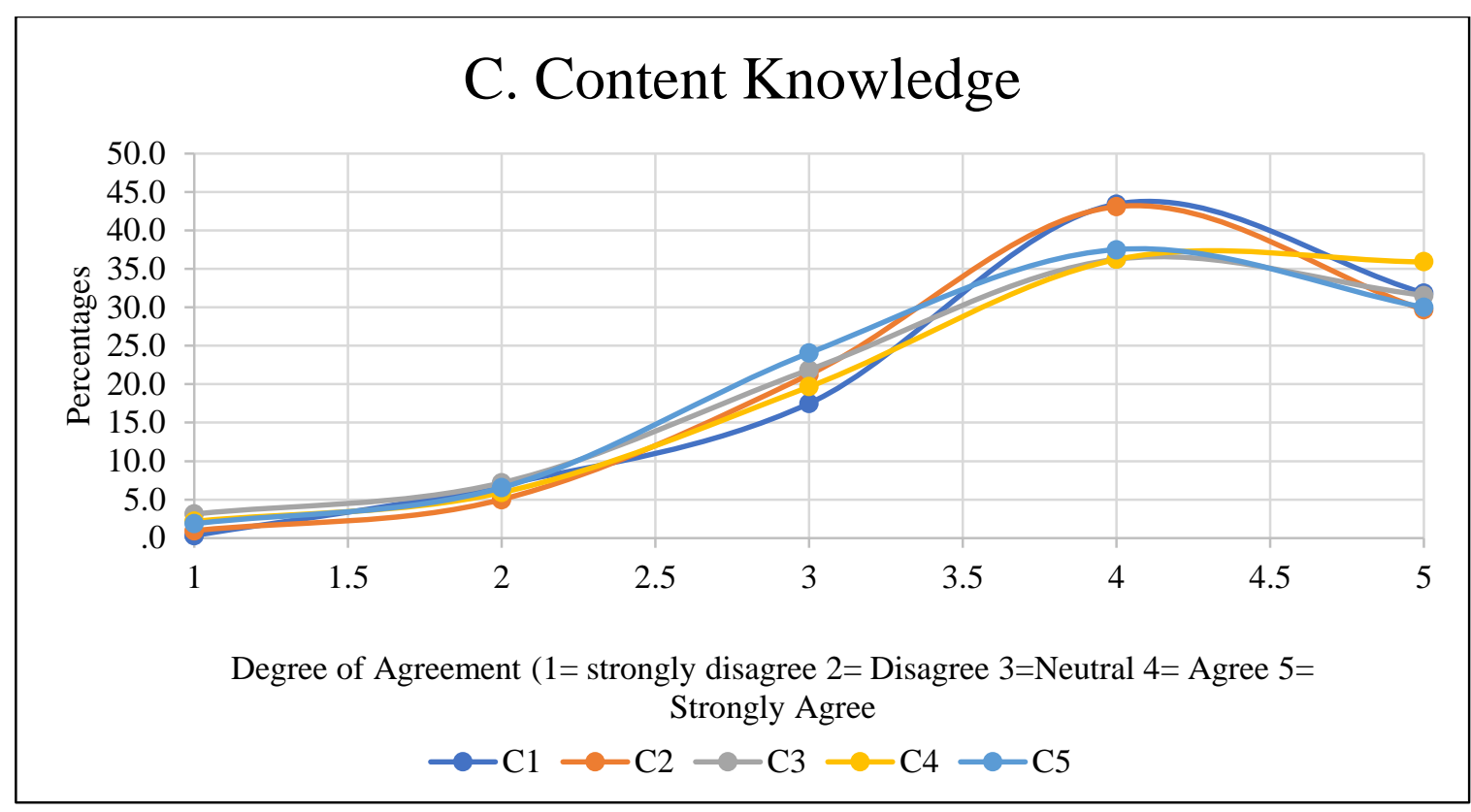

Figure 3. Indonesian Arabic teachers' Content knowledge on the Arabic language

Figure 4 shows the overall agreement on Indonesian Arabic teachers' technological knowledge competence. It can be deducted from the graph that the participant teachers had less competence in the technological aspect when it comes to basic hardware of computers, i.e. CD-ROM, Motherboard, etc. (A6). However, teachers showed the most vigorous agreement in responding towards their competence in playing audio or video files on their computers (A2). Participant Indonesian Arabic language teachers also showed strong agreement on their competence to save files on the computer (A1).

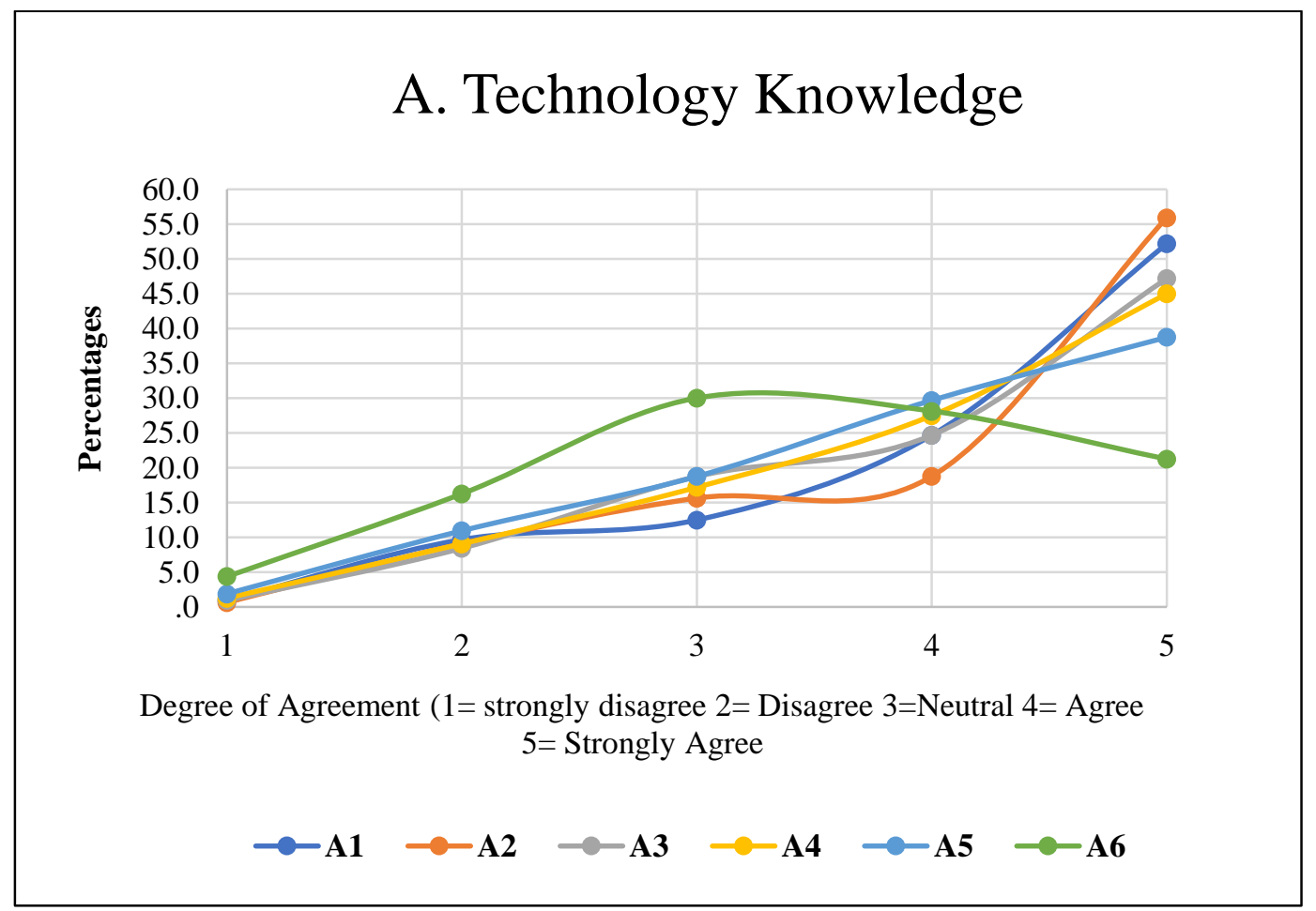

Figure 4. Indonesian Arabic Teachers Technological Knowledge 


\subsection{Teachers' Pedagogical Content Knowledge, Technological Pedagogical Knowledge and Technological Content Knowledge Contributing to TPACK}

Figure 5 depicts the participant Indonesian Arabic language teachers' pedagogical content knowledge. As mentioned in the methodology, the model's confirmatory analysis integrated teachers' pedagogical knowledge and pedagogical content knowledge in the same construct. So, in this construct, teachers' pedagogical knowledge and pedagogical content knowledge are simultaneously analyzed. The figure shows that Indonesian Arabic teachers had the highest agreement in their competence to react supportively to learners' reactions (E7). The participant teachers showed their lowest agreement to their perception of competence in using the target language, including metalanguage (E4). In general, participant Indonesian Arabic teachers showed a neutral response in almost all items (excluding E7) regarding pedagogical content knowledge in teaching Arabic as a foreign language.

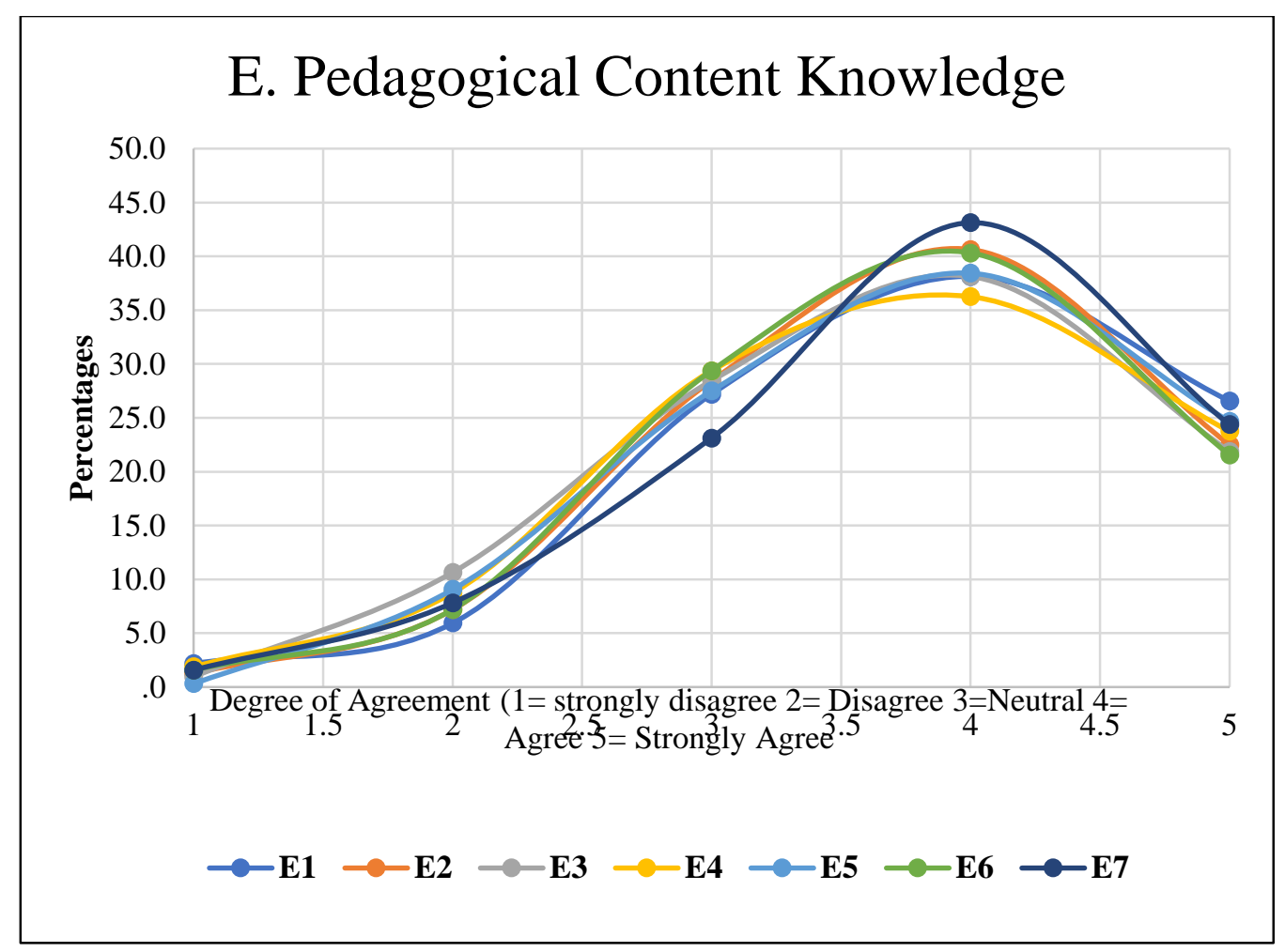

Figure 5. Indonesian Arabic teachers' Pedagogical Content Knowledge

Participant Indonesian Arabic language teachers' technological pedagogical knowledge is depicted in Figure 6. The figure represents teachers' competencies in applying technological approaches in teaching techniques. The figure also shows that participant teachers had the most agreement in their perception of competence in engaging students in solving authentic problems using digital technologies (B6). However, in terms of their competencies on adapting the use of technologies, in different teaching approaches, the participant Indonesian Arabic teachers showed their strongest agreement, (B2) at the same time, teachers had the lowest assumption of their competencies on designing relevant teaching exercises for Arabic language teaching (B4). 


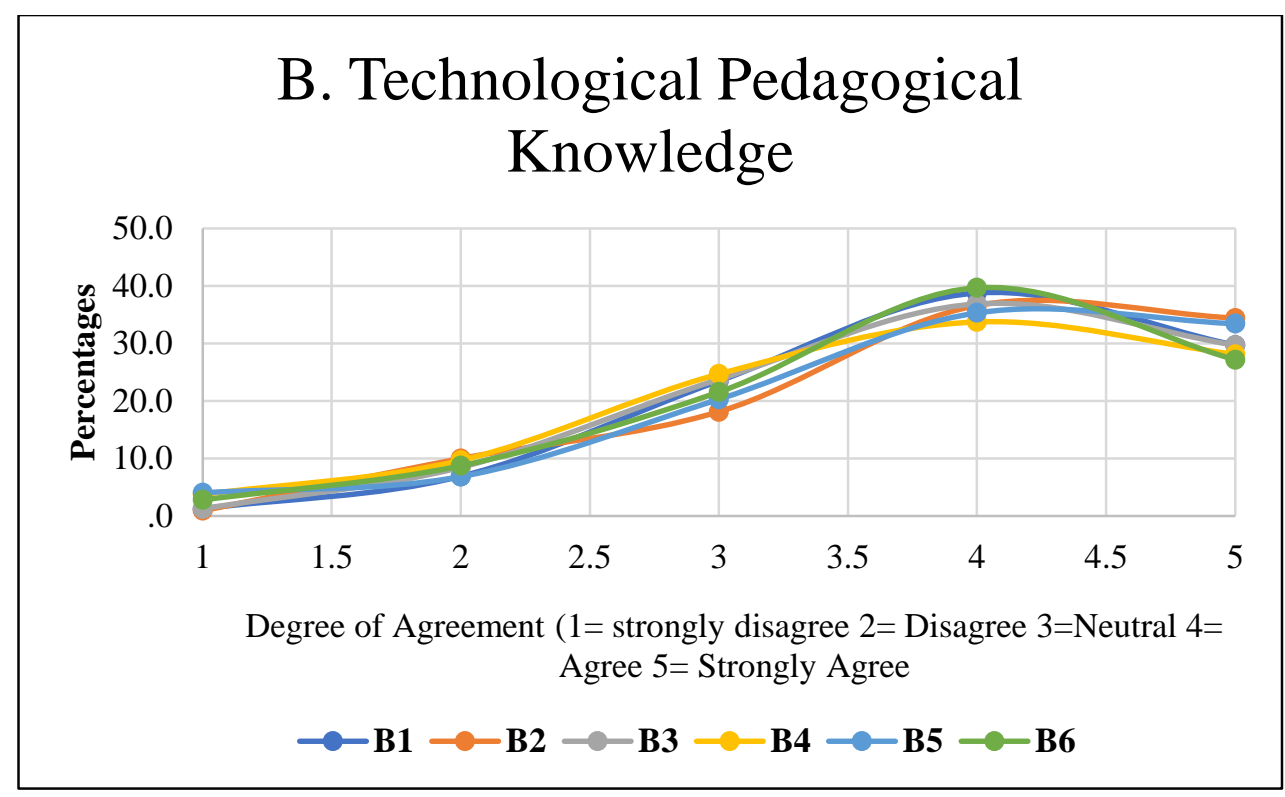

Figure 6. Indonesian Arabic teachers' Technological Pedagogical Knowledge

Participant Indonesian Arabic teachers' technological content knowledge is measured in this construct, amplified in Figure 7. This figure, in general, refers to a moderate competence on participant Indonesian Arabic teachers' technological content, considering a large percentage responded as neutral in each item (excluding D6). Participant teachers showed their highest agreement in knowing technologies to enhance students' Arabic grammar (D1). Their most robust agreement was on understanding the technologies used for listening to Arabic language speech (D6). Teachers showed their most neutral position on knowledge about technologies that can enhance students' vocabulary.

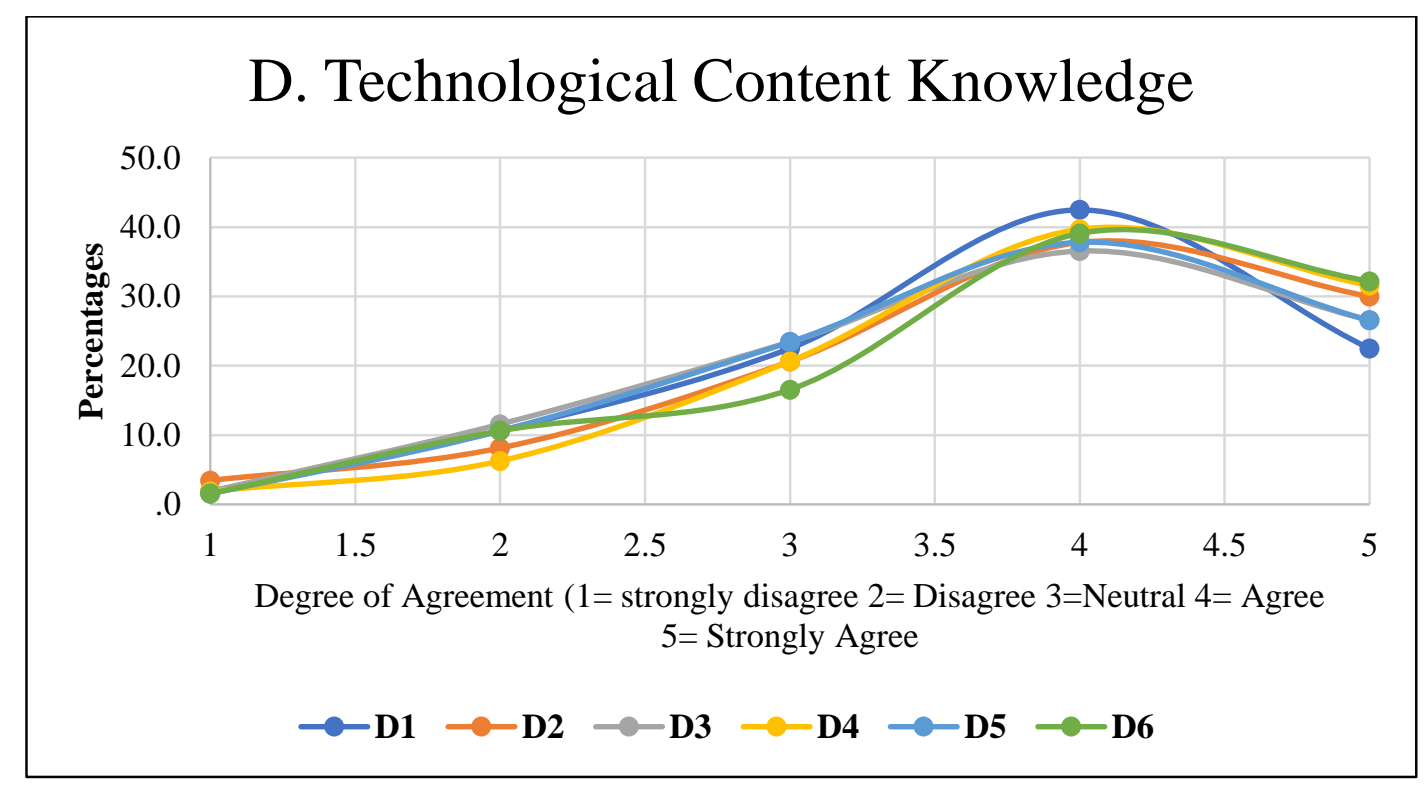

Figure 7. Indonesian Arabic Teachers' Technological Content Knowledge

\subsection{Teachers' Overall TPACK}

Participant Indonesian Arabic teachers' total TPACK is measured in the $6^{\text {th }}$ construct, represented in Figure 8. The figure, in general, shows a moderate position of the participant Arabic language 
teachers of Indonesia, considering approximately one-fourth of the participants' neutral position in all items under this construct. Teachers showed their highest agreement on using technologies effectively to communicate with students and peers (F1). Their lowest perceived competence was visible in their responses on facilitating intellectual understanding by using technologies to engage students with different cultures.

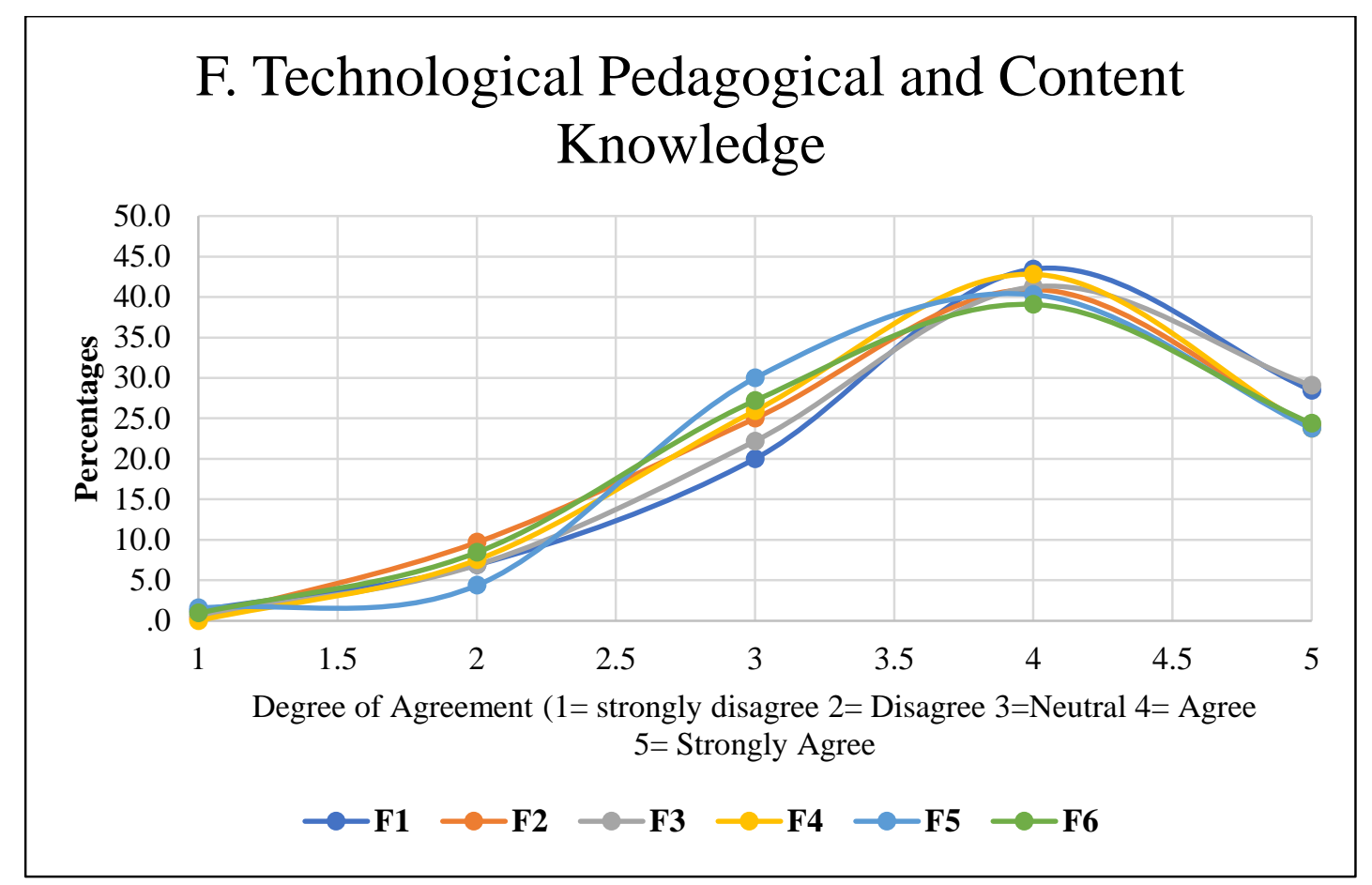

Figure 8. Indonesian Arabic teachers' Technological Pedagogical and Content Knowledge

To analyze the interrelation of the elements of TPACK, considering the elements are not separate, but rather connected with each other, all the constructs were analyzed comparatively, shown by the following figure, Figure 9. The graph represents teachers' strongest agreement in their competence on technological knowledge in teaching the Arabic language, which is one of the essential components of the pyramid of TPACK (Figure 2). Another fundamental element of the TPACK frame is content knowledge on the Arabic language, which from the figure can be seen as not reflecting firm agreement. Rather agreement is moderate in two items only, which are focused on monitoring their speech and writing in the Arabic language. The complex elements, technological content knowledge, pedagogical knowledge, and pedagogical content knowledge have a similar trend of agreements in their responses. However, technological pedagogical knowledge has less agreement than the other two. The top element, technological pedagogical and content knowledge, TPACK, has the same responses as the complex elements. 


\section{Overall Response to the TPACK survey}

$\longrightarrow$ Strongly Disagree $\longrightarrow$ Disagree $\longrightarrow$ Neutral $\longrightarrow$ Agree $\longrightarrow$ Strongly Agree

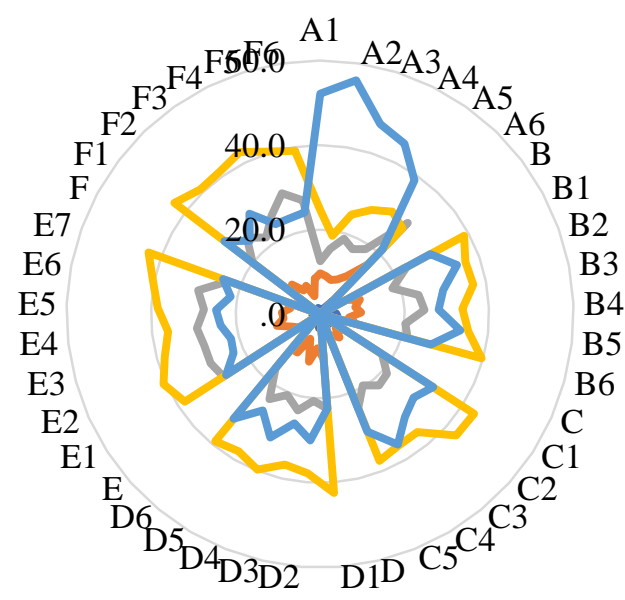

Figure 8. Indonesian Arabic Teachers' Technological Pedagogical and Content Knowledge

\section{Discussion}

The study sought to measure Indonesian Arabic language teachers' TPACK to explore their content knowledge, technological knowledge, pedagogical content knowledge, technological content knowledge, technological pedagogical knowledge, and overall technological pedagogical and content knowledge. The underlying theory in this study emerges from the philosophy that the elements of TPACK are not separate from each other; instead, each element sustains other elements to achieve the final or targeted TPACK of the teachers.

\subsection{CK TK, PCK, TCK, TPK Contributing to the Overall TPACK}

As amplified in Figure 2, this study conceptualizes content knowledge as the basic need for the other elements of the hierarchy of the overall TPACK. After content knowledge, technological knowledge is a vital primary component of TPACK to sustain the higher elements (PCK, TCK, and TPK). The findings show teachers' competencies for content knowledge of the Arabic language were very good, although it was less than their technological knowledge (Figure 9). This response can be justified by the open ended-question, asking the participant Arabic teachers what type of training or teacher development programs they had attended. Those who had attended some sort of training, either through in-service or pre-service courses or through special workshops, mentioned the efficacy of those training programs on implementing technology in their teaching. However, in Indonesia, Arabic is a foreign language even for teachers (Ritonga et al., 2020). Hence, it is not surprising that the teachers showed moderate competence in Arabic content knowledge.

Considering the argument from the literature that content knowledge cannot always be parallel to teachers' pedagogical content knowledge (Depaepe \& König, 2018), this study also arrives at similar findings. The participant teachers' agreement on their content knowledge of familiarity with Arabic language culture was higher than their pedagogical content knowledge to choose the target language to make the students familiar with the Arabic language culture (Figures 3, 5; items C5, E4). This 
difference in the teachers' content knowledge not reflecting in their teaching lies in the concept that teaching a foreign language needs more pedagogical techniques than only having content knowledge, which can be gained through adequate training and experience (Guerreiro, 2017). This can also result from the lack of research on Indonesian Arabic teachers' pedagogical content knowledge, leading to initiatives to improve teachers' pedagogical content knowledge. Nevertheless, the teachers' higher competence in Arabic content knowledge monitoring their speech or comprehension of Arabic texts is reflected in their pedagogical content knowledge measurement. They showed their strongest competence in responding to students' speech or texts (Figures 5 and 6; Items C2, C4, E7). The confidence level of the teachers can explain this result for having Arabic solid content knowledge and, thus, the competence to respond to students' reactions.

In terms of technological content knowledge, teachers' strong competence in playing audio and video files reflects their technological content knowledge with more vital competence in using audio or video files to help students learn new words (Figures 4 and 7; items C2, C4, A2). This again reflects the teachers' engagement in training related to Information Technology and, thus, strong competence in using technology for students' internalization of grammar and vocabulary (Al-khresheh \& Orak, 2021; Ismail et al., 2010). However, in general, participant Indonesian Arabic teachers' technological knowledge was higher than technological pedagogical knowledge, especially in terms of designing tasks for students using technology (Figures 4 and 6, items A6, B4). This result can be explained by teachers' lack of technological knowledge on intensive technical aspects of information technology, reflecting on their lack of competence to use ICT to design and utilize students' digital tasks. Several studies have emphasized the importance of technology to learn vocabulary (Yani \& Sara, 2018), and even transforming dictionaries in Indonesia (Taufiqurrochman, 2020). But lack of emphasis is given to improving teachers' competence in design-based learning using ICT.

\subsection{TPACK inclusive of all elements}

In comparing the overall TPACK of participant Indonesian Arabic teachers regarding their content knowledge and technological knowledge, and the complex components, TCK, TPK, and PCK, surprisingly, the technological aspect was more evident than content knowledge (Figure 9). Teachers have mentioned their stronger competence in using technology to communicate with or pursue teaching-learning activities with students in their TPACK (Figure 8). However, the intellectual aspect was the least strong in the overall TPACK of the Indonesian participant teachers (Figure 8, item F6), which reflects teachers' lack of pedagogical content knowledge on introducing Arabic language cultures, although having their strong Arabic content knowledge about that which has been discussed earlier (Figures 3 and 5; items C5, E4). This response crystallizes the need for teachers' training, not only oriented to using ICT to promote Arabic grammar and vocabulary but also shed light on the importance of the Arabic language to lead an Islamic lifestyle, respecting the Quran, Hadith, and other sources (Aziz et al., 2016).

\subsection{Pedagogical implications}

The study's pedagogical implication can be stipulated from the conceptualization of TPACK as a combination of 6 inter-related elements that sustain each other. Thus, it indicates that the Indonesian Arabic teachers should move beyond the simplest forms of knowledge (Arabic content knowledge, technological knowledge, and pedagogical knowledge) and move towards the complex forms of knowledge, where two or more simple forms of knowledge are merged to achieve the expected learning outcomes. This means that the Indonesian Arabic teachers having the Arabic CK, PK and TK 
should combine their CK with PK (performing PCK), technological aspects with Arabic CK and PK, etc.

\section{Limitations and Recommendations}

The study does not explore the impact of teachers' experience on their TPACK of Arabic language teaching. The study participants were purposefully chosen; as a result, the data need not reflect the global scenario of Indonesian Arabic teaching-learning practices.

The study recommends exploring the teachers' experiences and training on the TPACK of Indonesian Arabic teachers for educators and researchers. For the concerned authorities, the study suggests imparting adequate and proper training to the Arabic teachers to promote technology use in designing and assessing the Arabic language courses.

\section{Conclusion}

The study aimed to explore Arabic teachers' technological pedagogical and content knowledge for the first time in Indonesia. In general, it can be derived from the survey that the participant teachers had the most decisive competence in their technological aspects, which can be used for communicating with students or improving the students' grammar and vocabulary. The content knowledge of the participant teachers was the strongest in the monitoring of their speech and text. The participants' pedagogical content knowledge, technological content knowledge, and technological pedagogical knowledge reflected the need to promote pedagogical techniques beyond only grammar and vocabulary, more towards designing tasks using ICT and emphasizing the need to build the procedural link of Arabic language and Islamic studies, and language culture. The overall TPACK results showed the need to stress the students' intellectual growth through adequate and appropriate training of the Arabic teachers in Indonesia.

\section{References}

Ahmad, I. (2001). Teaching Islamic studies in the Non-Arab world: with or without Arabic? Journal of Muslim Minority Affairs, 21(2), 273-285. https://doi.org/10.1080/1360200120092851

Ahmadi, A., \& Ilmiani, A. M. (2020). The use of teaching media in Arabic language teaching during Covid-19 pandemic. Dinamika Ilmu. https://doi.org/10.21093/di.v20i2.2515

Al Lily, A. E., Ismail, A. F., Abunasser, F. M., \& Alqahtani, R. H. A. (2020). Distance education as a response to pandemics: Coronavirus and Arab culture. Technology in Society, 63, 101317. https://doi.org/10.1016/j.techsoc.2020.101317

Alayyar, G. M., Fisser, P., \& Voogt, J. (2012). Developing technological pedagogical content knowledge in pre-service science teachers: Support from: Blended learning. Australasian Journal of Educational Technology, 28(8), 1298-1316. https://doi.org/10.14742/ajet.773

Albantani, A. M., \& Madkur, A. (2019). Teaching Arabic in the era of Industrial Revolution 4.0 in Indonesia: Challenges and opportunities. ASEAN Journal of Community Engagement, 3(2), 12-31. https://doi.org/10.7454/ajce.v3i2.1063

Al-busaidi, F., Hashmi, A. Al, Musawi, A. Al., \& Kazem, A. (2016). Teachers' perceptions of the effectiveness of using Arabic language teaching software in Omani basic education. International Journal of Education and Development Using Information and Communication Technology, 12(2) 139-157. 
Alharbi, H. E. (2019). An Arabic assessment tool to measure technological pedagogical and content $\begin{array}{llll}\text { knowledge. Computers } & \text { and }\end{array}$ https://doi.org/10.1016/j.compedu.2019.103650

Ali, N., Hasanah, M., \& Prasetyo, A. (2020). The integration Of Qur'an and linguistic education based on ontology of Qur'anic concept in Quranic Arabic corpus. Ijaz Arabi Journal of Arabic Learning, 3(2). https://doi.org/10.18860/ijazarabi.v3i2.9769

Al-khresheh, M. (2020). The influence of anxiety on Saudi EFL learners' oral performance, University Aljouf humanities sciences journal, 6(8), 275-305.

Al-khresheh, M., \& Al-Ruwaili, S. (2020). An exploratory study on vocabulary learning strategies used by Saudi EFL learners. Journal of History Culture and Art Research, 9(2), 288-302. http://dx.doi.org/10.7596/taksad.v9i2.2616

Habibi, A., Razak, R., Yusop, F., \& Mukminin, A. (2019). Preparing future EFL teachers for effective technology integration: What do teacher educators say. Asian EFL Journal, 21(2), 9-30.

Al-khresheh, M., Khaerurrozikin, A., \& Zaid, A. (2020). The efficiency of using pictures in teaching speaking skills of non-native Arabic beginner students. Universal Journal of Educational Research, 8(3), 872 - 878. http://dx.doi/10.13189/ujer.2020.080318

Al-khresheh, M. (2021). Revisiting the effectiveness of Blackboard learning management system in teaching English in the era of COVID 19. World Journal of English Language, 12(1), 1-14. https://doi.org/10.5430/wjel.v12n1p1

Al-khresheh, M., \& Orak, D. S. (2021). The place of grammar instruction in the 21st century: Exploring global perspectives of English teachers towards the role of teaching grammar in EFL/ESL classrooms. World Journal of English Language, 11(1), 9-23. https://doi.org/10.5430/wjel.v11n1p9

Alkodimi, K. A., \& Al-Ahdal, A. A. M. H. (2021). Strategies of teaching writing at Saudi tertiary-level institutions: Reality and expectations. Arab World English Journal (AWEJ), 12(2)., 399- 413 https://dx.doi.org/10.24093/awej/vol12no2.27

Alwaleedi, M. A. (2017). Examining language-related episodes (LREs) of Arabic as a second language (ASL) learners during collaborative writing activities. Theory and Practice in Language Studies, 7(4), 256. https://doi.org/10.17507/tpls.0704.03

Alwaleedi, M. A., Gillies, R. M., \& Obaidul Hamid, M. (2019). Collaborative writing in Arabic as a second language (ASL) classrooms: A mixed-method study. Language, Culture and Curriculum, 32(2), 157-172. https://doi.org/10.1080/07908318.2018.1521422

Amer, M. (2020). Language learning difficulties reported by beginner-level learners of Arabic using online tools. Journal of Advances in Linguistics, 11, 19-35. https://doi.org/10.24297/jal.v11i.8654

Aziz, A. A., Ibrahim, M. A., Shaker, M. H., \& Nor, A. M. (2016). Teaching technique of Islamic Studies in higher learning institutions for non-Arabic speakers: Experience of faculty of Quranic and Sunnah studies and Tamhidi Centre, Universiti Sains Islam Malaysia. Universal Journal of Educational Research, 4(4), 755-760. https://doi.org/10.13189/ujer.2016.040412

Azizan, N. K., Mamat, A., \& Sahrir, M. S. (2017). Pedagogical content knowledge (PCK) among preservice teachers and their interest in the teaching of Arabic. The Online Journal of Islamic Education, 5(2), 1-9.

Baviskar, S. N., Todd Hartle, R., \& Whitney, T. (2009). Essential criteria to characterize constructivist 
teaching: Derived from a review of the literature and applied to five constructivist-teaching method articles. International Journal of Science Education, 31(4), 541-550. https://doi.org/10.1080/09500690701731121

Bernasek, L., \& Canning, J. (2009). Influences on the teaching of Arabic and Islamic studies in UK higher education: Connections and disconnections. Arts and Humanities in Higher Education, 8(3), 259-275. https://doi.org/10.1177/1474022209339954

Bhatti, A., Pathan, H., Tabieh, A., \& Hassan, A., (2020). Impact of Learner-learner Rapport on L2 Learning: A Study of Public Sector Universities in Sindh, Pakistan. The Asian EFL Journal,27 (4.6), 204-226.

Bingimlas, K. (2018). Investigating the level of teachers' knowledge in technology, pedagogy, and content (TPACK) in Saudi Arabia. South African Journal of Education, 38(3). https://doi.org/10.15700/saje.v38n3a1496

Bostancioğlu, A., \& Handley, Z. (2018). Developing and validating a questionnaire for evaluating the EFL 'Total PACKage': Technological Pedagogical Content Knowledge (TPACK) for English as a Foreign Language (EFL). Computer Assisted Language Learning, 31(5-6), 572-598. https://doi.org/10.1080/09588221.2017.1422524

Brantley-Dias, L., \& Ertmer, P. A. (2013). Goldilocks and TPACK: Is the construct "just right?" Journal of Research on Technology in Education, 46(2), 103-128. https://doi.org/10.1080/15391523.2013.10782615

Confrey, J. (1995). How compatible are radical constructivism, sociocultural approaches, and social constructivism? Routledge

Cooper, P. A. (1993). Paradigm shifts in designed instruction: from Behaviorism to Cognitivism to Constructivism. Educational Technology, 33(5), 12-19. http://www.jstor.org/stable/44428049

Cox, M. (1987). Knowledge and teaching: Foundations of the new reform. Harvard Educational Review, 57(1), 1-22.

Creswell, J. (2012). Educational researchplanning, conducting, and evaluating quantitative and qualitative research, 461-484.

Deci, E. L., \& Ryan, R. M. (2010). Self-determination. The Corsini Encyclopedia of Psychology, 1-2.

Deng, Z. (2018). Pedagogical content knowledge reconceived: bringing curriculum thinking into the conversation on teachers' content knowledge. Teaching and Teacher Education, 72, 155-164. https://doi.org/10.1016/j.tate.2017.11.021

Depaepe, F., \& König, J. (2018). General pedagogical knowledge, self-efficacy and instructional practice: Disentangling their relationship in pre-service teacher education. Teaching and Teacher Education, 69, 177-190. https://doi.org/10.1016/j.tate.2017.10.003

Drajati, N. A., Tan, L., Haryati, S., Rochsantiningsih, D., \& Zainnuri, H. (2018). Investigating English language teachers in developing TPACK and multimodal literacy. Indonesian Journal of Applied Linguistics, 7(3), 575-582. https://doi.org/10.17509/ijal.v7i3.9806

Gray, A. J. (1997). Constructivist teaching and learning. Saskatchewan School Trustees Association.

Guerreiro, S. (ed. . (2017). Pedagogical knowledge and the changing nature of the teaching profession. In Centre for Educational Research and Innovation. OECD. OECD Publishing. http://dx.doi.org/10.1787/9789264270695-en\%0Ahttp://www.oecd-

ilibrary.org/education/pedagogical-knowledge-and-the-changing-nature-of-the-teaching- 
profession_9789264270695-en

Haggag, H. M., \& Bakr, E. M.-E. (2020). Teachers' perceptions about language learning difficulties in English as a foreign language EFL classes. European Scientific Journal ESJ, 16(19), 1857-7881. https://doi.org/10.19044/esj.2020.v16n19p120

Hamdan Alghamdi, A. K. (2014). The road to culturally relevant pedagogy: expatriate teachers' pedagogical practices in the cultural context of Saudi Arabian higher education. McGill Journal of Education, 49(1), 201-226. https://doi.org/10.7202/1025778ar

Hassan, A., Kazi, A. S., \& Asmara Shafqat, Z. A. The Impact of Process Writing on the Language and Attitude of Pakistani English Learners. Asian EFL Journal, 27(4.3), 260-277.

Herring, M. C., Koehler, M. J., \& Mishra, P. (2016). Handbook of technological pedagogical content knowledge (TPACK) for educators: Second edition. In Handbook of Technological Pedagogical Content Knowledge (TPACK) for Educators: Second Edition. Routledge. https://doi.org/10.4324/9781315771328

Huitt, W. (2009). Humanism and open education. Educational Psychology Interactive. Valdosta State University.

Ismail, S., Almekhlafi, A., \& Al-Mekhlafy, M. (2010). Teachers' perceptions of the use of technology in teaching languages in United Arab Emirates' schools. International Journal for Research in Education, 27(1), 37-56.

Jwaifell, M., Abu-Omar, R., \& Al-Tarawneh, M. (2018). The readiness of Arabic language teachers for integrating flipped classroom: Case of Ma'an. International Journal of Instruction, 11(4), 855868. https://doi.org/10.12973/iji.2018.11454a

Karimizadeh, N., \& Abolghasemi, M. (2016). The Islamic and religious education in Malaysian schools: from past up to now introduction. In International Academic Journal of Innovative Research, 3(4). www.iaiest.com

Koehler, M. J., \& Mishra, P. (2005). What happens when teachers design educational technology? the development of technological pedagogical content knowledge. Journal of Educational Computing Research, 32(2), 131-152. https://doi.org/10.2190/0EW7-01WB-BKHL-QDYV

Koehler, M. J., Mishra, P., \& Cain, W. (2013). What is technological pedagogical content knowledge (TPACK)? Journal of Education, 193(3), 13-19. https://doi.org/10.1177/002205741319300303

Koh, J. H. L., \& Chai, C. S. (2016). Seven design frames that teachers use when considering technological pedagogical content knowledge (TPACK). Computers and Education, 102, 244-257. https://doi.org/10.1016/j.compedu.2016.09.003

Mahundu, G. F. (2020). COVID-19 Disease pandemic lockdown: schools closure and students elearning options in Tanzania. SSRN Electronic Journal. https://doi.org/10.2139/ssrn.3698554

Maslow, A. H. (1989). A theory of human motivation. Readings in Managerial Psychology, 20. 20 35.

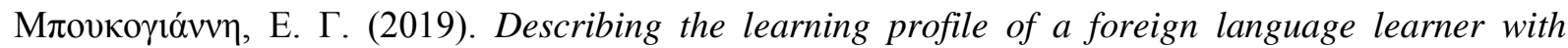
cooccurring learning difficulties and discussing implications for methodological choices: a single

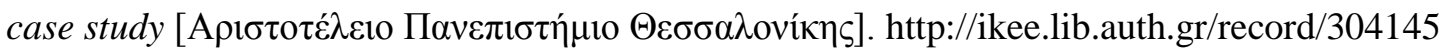

Muhaimin, M., Habibi, A., Mukminin, A., Saudagar, F., Pratama, R., Wahyuni, S., Sadikin, A., \& Indrayana, B. (2019). A sequential explanatory investigation of TPACK: Indonesian science teachers' survey and perspective. Journal of Technology and Science Education, 9(3), 269-281. 
https://doi.org/10.3926/jotse.662

Naderifar, M., Goli, H., \& Ghaljaie, F. (2017). Snowball sampling: A purposeful method of sampling in qualitative research. Strides in Development of Medical Education, 14(3), 1-6. https://doi.org/10.5812/sdme.67670

Niess, M. L. (2011). Investigating TPACK: Knowledge growth in teaching with technology. Journal of Educational Computing Research, 44(3), 299-317. https://doi.org/10.2190/EC.44.3.c

Orak, D. S., \& Al-khresheh, M. (2021). In between 21st century skills and constructivism in ELT: Designing a model derived from a narrative literature review. World Journal of English Language, 11(2), 166-176. https://doi.org/10.5430/wjel.v11n2p166

Peters, G.-J. (2018). The alpha and the omega of scale reliability and validity: why and how to abandon Cronbach's alpha and the route towards more comprehensive assessment of scale quality.

Ratheeswari, K. (2018). Recent trend of teaching methods in education" organised by Sri Sai Bharath College of Education Dindigul-624710. India Journal of Applied and Advanced Research, 2018(3), 45-47. https://doi.org/10.21839/jaar.2018.v3S1.165

Ritonga, M., Asrina, Widayanti, R., Alrasi, F., Julhadi, \& Halim, S. (2020). Analysis of Arabic language learning at higher education institutions with multi-religion students. Universal Journal of Educational Research, 8(9), 4333-4339. https://doi.org/10.13189/ujer.2020.080960

Sai, Y. (2017). "Arabic is not my language...": Debates over teaching of Arabic in Irish muslim schools. Journal of Muslim Minority Affairs, 37(4), 442-453. https://doi.org/10.1080/13602004.2017.1399602

Saidah, U., Bin-Tahir, S. Z., \& Mufidah, N. (2018). Arabic teachers' competence: a case of madrasah schools in Maluku. Ijaz Arabi Journal of Arabic Learning, 1(2), 139-150. https://doi.org/10.18860/ijazarabi.v1i2.5584

Sains, U. (2019). Towards the enhancement of Arabic language and Islamic studies in Nigerian schools in the 21. Journal of Arts and Social Sciences Education, 1(2), 108-116. https://www.alhikmah.edu.ng/ajasse/index.php/ajasse/article/view/28

Schunk, D. H. (1991). Self-efficacy and academic motivation. Educational Psychologist, 26(3-4), 207-231.

Schwartz, M., \& Asli, A. (2014). Bilingual teachers' language strategies: The case of an ArabicHebrew kindergarten in Israel. Teaching and Teacher Education, 38, 22-32. https://doi.org/10.1016/j.tate.2013.10.013

Setiawan, H., \& Phillipson, S. (2020). The correlation between social media usage in academic context and self-efficacy towards TPACK of prospective science teachers in Indonesia. Journal of Science Learning, 3(2), 106-116. https://doi.org/10.17509/jsl.v3i2.22242

Shulman, L. S. (2019). Those who understand: Knowledge growth in teaching. Profesorado, 23(3), 269-295. https://doi.org/10.30827/profesorado.v23i3.11230

Sibgatullina, G. (2020). Language maintenance, revival and shift in the sociology of religion. In Current Issues in Language Planning, 21(4). Multilingual Matters. https://doi.org/10.1080/14664208.2020.1763023

Sonmark, K., Révai, N., Gottschalk, F., Deligiannidi, K., \& Burns, T. (2017). Understanding teachers' pedagogical knowledge: report on an international pilot study. Oecd, 159, 150. 
https://doi.org/10.1787/43332ebd-en

Sulaiman, K. O. (2015). The effects of Information And Communication Technologies (ICT) on the teachings/ learning of Arabic and Islamic Studies. Ar-Raniry, International Journal of Islamic Studies. https://doi.org/10.20859/jar.v2i1.27

Supriyatno, T., Susilawati, S., Hassan, A., (2020). E-learning development in improving students' critical thinking ability. Cypriot Journal of Educational Sciences, 15(5), 1099-1106. https://doi.org/10.18844/cjes.v15i5.5154

Taufiqurrochman, R. (2020). The transformation of the Arabic Dictionary in Indonesia from the morphological system to the alphabetic system and its effect on Arabic language learning. International Journal of Innovation, Creativity and Change, 13(8), 632-645. http://repository.uinmalang.ac.id/6385/

Tohe, A., \& Malang, U. N. (2018). Arabic language at the crossroad: a case study in Indonesia. In Prosiding Pertemuan Ilmiah Internasional Bahasa Arab. http://prosiding.imla.or.id/index.php/pinba/article/view/83

Tweddell, J. S. (2015). Where do we go now? Journal of Thoracic and Cardiovascular Surgery, 150(6), 1453-1454. https://doi.org/10.1016/j.jtcvs.2015.07.009

Valtonen, T., Sointu, E., Kukkonen, J., Mäkitalo, K., Hoang, N., Häkkinen, P., Järvelä, S., Näykki, P., Virtanen, A., Pöntinen, S., Kostiainen, E., \& Tondeur, J. (2019). Examining pre-service teachers' Technological Pedagogical Content Knowledge as evolving knowledge domains: A longitudinal approach. Journal of Computer Assisted Learning, 35(4), 491-502. https://doi.org/10.1111/jcal.12353

Vygotsky, L. S. (1980). Mind in society: The development of higher psychological processes. Harvard university press.

Wahba, K. M., England, L., \& Taha, Z. A. (2017). Handbook for Arabic language teaching professionals in the 21st century. In Handbook for Arabic Language Teaching Professionals in the 21st Century (Vol. 2). Routledge. https://doi.org/10.4324/9781315676111

Wekke, I. S. (2017). Arabic learning material of higher education Muslim community North Sulawesi. Dinamika Ilmu, 17(2), 175-189. https://doi.org/10.21093/di.v17i2.863

Willermark, S. (2018). Technological pedagogical and content knowledge: A review of empirical studies published from 2011 to 2016. Journal of Educational Computing Research, 56(3), 315343. https://doi.org/10.1177/0735633117713114

Yani, A., \& Sara, S. (2018). The instructional materials of the Arabic language teaching for nonArabic speakers in the Republic of Indonesia: a Typical Study of the State University of Malang, Indonesia. European Journal of Education Studies, 5(6), 83-94. https://doi.org/10.5281/zenodo.1488655

Zakaria, Z. M., Atan, A., Yusuf, R., \& Mei, S. Y. (2019). Content knowledge competency of Arabic language teacher trainees during teaching practice. International Journal of Academic Research in Business and Social Sciences, 9(9). https://doi.org/10.6007/ijarbss/v9-i9/6295

ZurqoniRetnawati, H., Rahmatullah, S., Djidu, H., \& Apino, E. (2020). Has arabic language learning been successfully implemented? International Journal of Instruction, 13(4), 715-730. https://doi.org/10.29333/iji.2020.13444a 


\section{AUTHOR BIODATA}

Dr. Titin Nurhayati Ma'mun is an associate Professor at the Faculty of Cultural Sciences, Padjadjaran University, where her research and teaching focus on Arabic literature, philology, and cultural sciences.

Dr. Ade Kosasih is an Associate Professor at the Faculty of Cultural Sciences, Padjadjaran University, where his research and teaching focus on Arabic literature, philology, and Islamology.

Yani Rohmayani is a doctoral candidate and lecturer at the Faculty of Cultural Sciences, Padjadjaran University, where research and teaching focus on Arabic literature, philology, and cultural studies.

Eka Kurkia Firmansyah is a lecturer at the Faculty of Cultural Sciences, Padjadjaran University, where research and teaching focus on Arabic literature, linguistics, philology, and cultural studies.

Dr. Mohammad H. Al-khresheh is an Assistant Professor of Applied Linguistics. His research interest areas include but are not limited to first-second language acquisition, language teaching methods, psycholinguistics, comparative linguistics, and translation

\section{Appendix 1}

Table 1. Item specific Cronbach Alpha value

\begin{tabular}{|c|c|c|c|c|}
\hline \multicolumn{5}{|l|}{ Item-Total Statistics } \\
\hline Items & $\begin{array}{|lr|}\text { Scale } & \text { Mean } \\
\text { if } & \text { Item } \\
\text { Deleted } & \end{array}$ & $\begin{array}{l}\text { Scale Variance } \\
\text { if Item Deleted }\end{array}$ & $\begin{array}{l}\text { Corrected Item- } \\
\text { Total Correlation }\end{array}$ & $\begin{array}{l}\text { Cronbach's Alpha } \\
\text { if Item Deleted }\end{array}$ \\
\hline $\begin{array}{l}\text { A1. I know how to save data into/from a } \\
\text { digital device (i.e. flash disk, USB stick, CD) }\end{array}$ & 134.68 & 472.351 & .343 & .955 \\
\hline $\begin{array}{l}\text { A2. I know how to play audio and video files } \\
\text { on my computer }\end{array}$ & 134.65 & 472.542 & .338 & .955 \\
\hline $\begin{array}{l}\text { A3. I know how to use computer mediated } \\
\text { communication (CMC) technologies (e.g. } \\
\text { email, chat) }\end{array}$ & 134.77 & 470.330 & .391 & .955 \\
\hline $\begin{array}{l}\text { A4. I know how to record video files (i.e. } \\
\text { using a video camera) }\end{array}$ & 134.79 & 465.769 & .490 & .954 \\
\hline $\begin{array}{l}\text { A5. I know how to use generic office } \\
\text { applications (i.e. Word, PowerPoint, and } \\
\text { Excel) }\end{array}$ & 134.93 & 464.769 & .492 & .954 \\
\hline $\begin{array}{l}\text { A6. I know about basic computer hardware } \\
\text { (i.e. CD-ROM, mother-board, RAM) and } \\
\text { their functions }\end{array}$ & 135.40 & 458.391 & .609 & .953 \\
\hline $\begin{array}{l}\text { B1. I can choose technologies that enhance } \\
\text { students' learning for a lesson }\end{array}$ & 134.97 & 459.745 & .693 & .953 \\
\hline $\begin{array}{l}\text { B2. I can adapt the use of the technologies } \\
\text { that I am learning about to different teaching } \\
\text { activities }\end{array}$ & 134.92 & 459.548 & .661 & .953 \\
\hline $\begin{array}{l}\text { B3. I can choose technologies that enhance } \\
\text { the teaching approaches for a lesson }\end{array}$ & 135.00 & 457.398 & .729 & .952 \\
\hline $\begin{array}{l}\text { B4. I can design relevant learning } \\
\text { experiences to promote student learning, } \\
\text { using technology }\end{array}$ & 135.12 & 455.408 & .698 & .952 \\
\hline $\begin{array}{l}\text { B5. I can choose technologies to be used in } \\
\text { assessment }\end{array}$ & 134.98 & 456.407 & .681 & .953 \\
\hline $\begin{array}{l}\text { B6. I can engage students in solving } \\
\text { authentic problems using digital technologies } \\
\text { and resources }\end{array}$ & 135.06 & 458.843 & .662 & .953 \\
\hline
\end{tabular}




\begin{tabular}{|c|c|c|c|c|}
\hline $\begin{array}{l}\text { C1. I can monitor my own writing for } \\
\text { accuracy }\end{array}$ & 134.86 & 465.785 & .581 & .953 \\
\hline $\begin{array}{l}\text { C2. I can monitor my own speech for } \\
\text { accuracy }\end{array}$ & 134.90 & 469.303 & .490 & .954 \\
\hline $\begin{array}{l}\text { C3. I can comprehend Arabic speech } \\
\text { accurately }\end{array}$ & 134.99 & 470.125 & .394 & .955 \\
\hline C4, I can comprehend Arabic texts accurately & 134.87 & 471.439 & .383 & .955 \\
\hline $\begin{array}{l}\text { C5. I am familiar with the culture(s) of } \\
\text { target language communities }\end{array}$ & 134.98 & 468.307 & .466 & .954 \\
\hline $\begin{array}{l}\text { D1. I know about technologies that I can use } \\
\text { to teach Arabic language grammar }\end{array}$ & 135.12 & 463.324 & .581 & .953 \\
\hline $\begin{array}{l}\text { D2. I know about technologies that I can use } \\
\text { to teach reading in Arabic }\end{array}$ & 135.02 & 460.714 & .600 & .953 \\
\hline $\begin{array}{l}\text { D3. I know about technologies that I can use } \\
\text { to teach writing in Arabic }\end{array}$ & 135.11 & 460.380 & .621 & .953 \\
\hline $\begin{array}{l}\text { D4. I know about technologies that I can use } \\
\text { to teach Arabic vocabulary }\end{array}$ & 134.92 & 462.352 & .617 & .953 \\
\hline $\begin{array}{l}\text { D5. I know about technologies that I can use } \\
\text { to teach pronunciation of Arabic words }\end{array}$ & 135.08 & 461.855 & .603 & .953 \\
\hline $\begin{array}{l}\text { D6. I know about technologies that I can use } \\
\text { to teach listening in Arabic }\end{array}$ & 134.96 & 459.591 & .647 & .953 \\
\hline $\begin{array}{l}\text { E1. I can assess student learning in multiple } \\
\text { ways }\end{array}$ & 135.04 & 458.688 & .708 & .952 \\
\hline $\begin{array}{l}\text { E2. I can choose an appropriate approach to } \\
\text { teach learners (i.e. communicative approach, } \\
\text { direct method) }\end{array}$ & 135.09 & 461.628 & .668 & .953 \\
\hline $\begin{array}{l}\text { E3. I can facilitate learning through creating } \\
\text { opportunities for individual, partner, group } \\
\text { and whole class work }\end{array}$ & 135.16 & 459.301 & .699 & .952 \\
\hline $\begin{array}{l}\text { E4. I can plan when and how to use the target } \\
\text { language, including meta-language I may } \\
\text { need in the classroom }\end{array}$ & 135.14 & 461.381 & .630 & .953 \\
\hline E5. I can keep students on task & 135.07 & 463.283 & .620 & .953 \\
\hline $\begin{array}{l}\text { E6, I can identify linguistic problems } \\
\text { experienced by learners (i.e. phonological, } \\
\text { lexical or grammatical problems) }\end{array}$ & 135.12 & 462.070 & .651 & .953 \\
\hline $\begin{array}{l}\text { E7. I can react supportively to learners' } \\
\text { interaction }\end{array}$ & 135.04 & 461.722 & .649 & .953 \\
\hline $\begin{array}{l}\text { F1. I can use technology effectively to } \\
\begin{array}{l}\text { communicate relevant information to } \\
\text { students and peers }\end{array}\end{array}$ & 134.94 & 460.824 & .683 & .953 \\
\hline $\begin{array}{l}\text { F2. I can use a range of technologies that } \\
\text { enable students to become active participants }\end{array}$ & 135.07 & 459.886 & .709 & .952 \\
\hline $\begin{array}{l}\text { F3. I can select technologies to use in my } \\
\text { classroom that enhance what I teach, how I } \\
\text { teach, and what students learn }\end{array}$ & 134.94 & 460.739 & .698 & .953 \\
\hline $\begin{array}{l}\text { F4. I can use a range of technologies to help } \\
\text { students pursue their individual curiosities }\end{array}$ & 135.02 & 462.908 & .671 & .953 \\
\hline $\begin{array}{l}\text { F5. I can provide equitable access to digital } \\
\text { language learning tools and resources }\end{array}$ & 135.05 & 461.427 & .689 & .953 \\
\hline \begin{tabular}{|l} 
F6. I can facilitate intercultural \\
understanding by using technology to engage \\
students with different cultures
\end{tabular} & 135.08 & 462.825 & .623 & .953 \\
\hline
\end{tabular}




\section{Appendix 2}

Table 2. Descriptive statistics of the results

\begin{tabular}{|c|c|c|c|c|c|c|}
\hline Items & $\mathrm{N}$ & $\begin{array}{l}\text { Ran } \\
\text { ge }\end{array}$ & $\begin{array}{l}\text { Minimu } \\
\mathrm{m}\end{array}$ & $\begin{array}{l}\text { Maxim } \\
\text { um }\end{array}$ & Mean & $\begin{array}{l}\text { Std. } \\
\text { Deviati } \\
\text { on }\end{array}$ \\
\hline $\begin{array}{l}\text { A1. I know how to save data into/from a digital device (i.e. flash } \\
\text { disk, USB stick, CD) }\end{array}$ & 320 & 4 & 1 & 5 & 4.18 & 1.045 \\
\hline A2. I know how to play audio and video files on my computer & 320 & 4 & 1 & 5 & 4.20 & 1.047 \\
\hline $\begin{array}{l}\text { A3. I know how to use computer mediated communication } \\
\text { (CMC) technologies (e.g. email, chat) }\end{array}$ & 320 & 4 & 1 & 5 & 4.09 & 1.038 \\
\hline A4. I know how to record video files (i.e. using a video camera) & 320 & 4 & 1 & 5 & 4.06 & 1.047 \\
\hline $\begin{array}{l}\text { A5. I know how to use generic office applications (i.e. Word, } \\
\text { PowerPoint, and Excel) }\end{array}$ & 320 & 4 & 1 & 5 & 3.92 & 1.086 \\
\hline $\begin{array}{l}\text { A6. I know about basic computer hardware (i.e. CD-ROM, } \\
\text { mother-board, RAM) and their functions }\end{array}$ & 320 & 4 & 1 & 5 & 3.46 & 1.125 \\
\hline $\begin{array}{l}\text { B1. I can choose technologies that enhance students' learning for } \\
\text { a lesson }\end{array}$ & 320 & 4 & 1 & 5 & 3.89 & .953 \\
\hline $\begin{array}{l}\text { B2. I can adapt the use of the technologies that I am learning } \\
\text { about to different teaching activities }\end{array}$ & 320 & 4 & 1 & 5 & 3.93 & 1.004 \\
\hline $\begin{array}{l}\text { B3. I can choose technologies that enhance the teaching } \\
\text { approaches for a lesson }\end{array}$ & 320 & 4 & 1 & 5 & 3.85 & .983 \\
\hline $\begin{array}{l}\text { B4. I can design relevant learning experiences to promote student } \\
\text { learning, using technology }\end{array}$ & 320 & 4 & 1 & 5 & 3.73 & 1.088 \\
\hline B5. I can choose technologies to be used in assessment & 320 & 4 & 1 & 5 & 3.87 & 1.080 \\
\hline $\begin{array}{l}\text { B6. I can engage students in solving authentic problems using } \\
\text { digital technologies and resources }\end{array}$ & 320 & 4 & 1 & 5 & 3.80 & 1.026 \\
\hline C1. I can monitor my own writing for accuracy & 320 & 4 & 1 & 5 & 4.00 & .894 \\
\hline C2. I can monitor my own speech for accuracy & 320 & 4 & 1 & 5 & 3.96 & .891 \\
\hline C3. I can comprehend Arabic speech accurately & 320 & 4 & 1 & 5 & 3.86 & 1.042 \\
\hline C4, I can comprehend Arabic texts accurately & 320 & 4 & 1 & 5 & 3.98 & .997 \\
\hline $\begin{array}{l}\text { C5. I am familiar with the culture(s) of target language } \\
\text { communities }\end{array}$ & 320 & 4 & 1 & 5 & 3.87 & .979 \\
\hline $\begin{array}{l}\text { D1. I know about technologies that I can use to teach Arabic } \\
\text { language grammar }\end{array}$ & 320 & 4 & 1 & 5 & 3.73 & .987 \\
\hline $\begin{array}{l}\text { D2. I know about technologies that I can use to teach reading in } \\
\text { Arabic }\end{array}$ & 320 & 4 & 1 & 5 & 3.83 & 1.056 \\
\hline $\begin{array}{l}\text { D3. I know about technologies that I can use to teach writing in } \\
\text { Arabic }\end{array}$ & 320 & 4 & 1 & 5 & 3.74 & 1.034 \\
\hline $\begin{array}{l}\text { D4. I know about technologies that I can use to teach Arabic } \\
\text { vocabulary }\end{array}$ & 320 & 4 & 1 & 5 & 3.93 & .969 \\
\hline
\end{tabular}




\begin{tabular}{|c|c|c|c|c|c|c|}
\hline $\begin{array}{l}\text { D5. I know about technologies that I can use to teach } \\
\text { pronunciation of Arabic words }\end{array}$ & 320 & 4 & 1 & 5 & 3.77 & 1.008 \\
\hline $\begin{array}{l}\text { D6. I know about technologies that I can use to teach listening in } \\
\text { Arabic }\end{array}$ & 320 & 4 & 1 & 5 & 3.90 & 1.023 \\
\hline E1. I can assess student learning in multiple ways & 320 & 4 & 1 & 5 & 3.81 & .969 \\
\hline $\begin{array}{l}\text { E2. I can choose an appropriate approach to teach learners } \\
\text { (i.e.communicative approach, direct method) }\end{array}$ & 320 & 4 & 1 & 5 & 3.76 & .924 \\
\hline $\begin{array}{l}\text { E3. I can facilitate learning through creating opportunities for } \\
\text { individual, partner, group and whole class work }\end{array}$ & 320 & 4 & 1 & 5 & 3.69 & .960 \\
\hline $\begin{array}{l}\text { E4. I can plan when and how to use the target language, including } \\
\text { meta-language I may need in the classroom }\end{array}$ & 320 & 4 & 1 & 5 & 3.71 & .985 \\
\hline E5. I can keep students on task & 320 & 4 & 1 & 5 & 3.78 & .931 \\
\hline $\begin{array}{l}\text { E6, I can identify linguistic problems experienced by learners } \\
\text { (i.e.phonological, lexical or grammatical problems) }\end{array}$ & 320 & 4 & 1 & 5 & 3.73 & .932 \\
\hline E7. I can react supportively to learners' interaction & 320 & 4 & 1 & 5 & 3.81 & .946 \\
\hline $\begin{array}{l}\text { F1. I can use technology effectively to communicate relevant } \\
\text { information to students and peers }\end{array}$ & 320 & 4 & 1 & 5 & 3.91 & .931 \\
\hline $\begin{array}{l}\text { F2. I can use a range of technologies that enable students to } \\
\text { become active participants }\end{array}$ & 320 & 4 & 1 & 5 & 3.79 & .929 \\
\hline $\begin{array}{l}\text { F3. I can select technologies to use in my classroom that enhance } \\
\text { what I teach, how I teach, and what students learn }\end{array}$ & 320 & 4 & 1 & 5 & 3.91 & .916 \\
\hline $\begin{array}{l}\text { F4. I can use a range of technologies to help students pursue their } \\
\text { individual curiosities }\end{array}$ & 320 & 3 & 2 & 5 & 3.83 & .877 \\
\hline $\begin{array}{l}\text { F5. I can provide equitable access to digital language learning } \\
\text { tools and resources }\end{array}$ & 320 & 4 & 1 & 5 & 3.80 & .904 \\
\hline $\begin{array}{l}\text { F6. I can facilitate intercultural understanding by using } \\
\text { technology to engage students with different cultures }\end{array}$ & 320 & 4 & 1 & 5 & 3.78 & .943 \\
\hline Valid N (listwise) & 320 & & & & & \\
\hline
\end{tabular}

